\title{
Mlčení v textech Maxima Gorkého jako způsob nepř́mé promluvy o světě
}

\author{
Zdeněk Pechal (Olomouc)
}

\begin{abstract}
Abstrakt
Stat' konstatuje, že vědecké biografie M. Gorkého jsou založeny na autobiografických uměleckých textech. Autor ve svých dílech mlčí. Slovo uměleckého textu nemůže být ztotožněno s autorem. Gorkého texty vypovídaji o autorovi pouze neprímo. Za důležité pro pochopení Gorkého vztahu ke světu lze pokládat absenci hodnotících komentárư v jeho uměleckých textech. Gorkého poetika je založena na výstižné portretizaci dějů, situací a postav v jejich pohybu a proměně. Gorkého lineární nesyžetové poetika nesměřuje ani k jednotícímu významu, ani k hodnotícímu komentáŕi, ale zůstává ve stádiu stále se obnovující otázky. Gorkij vyslovil vše, co chtěl a stále se vrací k otázce o smyslu toho, co vyslovil. Prostřednictvím uměleckých textů je možné sestavit portrét Gorkého, který mlčí. Gorkij se prostřednictvím nejlepších uměleckých textů nikdy prímo nevyslovil k dění v Rusku. Složitost světa mu bránila př́močaře se vyslovit k postavení člověka ve světě a jeho vztahu k realitě. Jeho díla vyjádřlla bezmocnost člověka se ve světě orientovat. Jednoduché vyjadřování patři do oblasti Gorkého publicistiky. Tato situace vytvář́ možnou paralelu ke kontroverzním situacím ve skutečném životě Maxima Gorkého. Gorkého umělecké texty vyjadřuji jeho skutečné a vždy nepřímé chápání světa.
\end{abstract}

\section{Klíčová slova}

Maxim Gorkij; román; reflektor; umělecký text; publicistika; obraz autora; autorský komentár; význam slova; neprímé hodnocení reality; svět v okamžiku pohybu a proměny jako objekt románu; umění jako intuitivní a živelný vjem reality

\section{Abstract \\ Silence in the Texts of Maxim Gorky as a Way of Indirect Talks about the World}

The article notes that the scientific biography M. Gorky are based on the art and autobiographical texts. The author in his art works remain silent. The word of art text can not be identified with the author. Gorky's novels speak about the author only indirectly. The absence of evaluation comments can be considered important to the understanding Gorky's relationship to the world. Gorky's poetics is based on a concise portrait of events, situations and characters in their movement and transformation. Gorky linear and non plot (non story) poetics seeks neither to have the unifying significance even to the evaluation comments, but still remains at the stage of constant renewal issues. Gorky expressed everything he wanted, and still comes back to the question about the meaning of what is spoken. The Gorky's portrait is possible to assemble only throught artistic text but Gorky as an author is silent. Gorky did not speak directly on events in Russia through the best novels he wrote. He was limited by complexity of the word to express directly assessment of man's place in the world and his relationship to the world. Gorky's works expressed the helplessness of man in the world to navigate. Simple expressions belong in Gorky journalism. This situation creates a possible parallel to controversial situations in real life of Maxim Gorky. Gorky's artistic texts express his true and always indirect understanding of the world. 


\section{Key words}

Maxim Gorky; a novel reflector; artistic text; journalism; image of author; author comment; meaning; indirect reality; world at the time of movement and transformation as a novel object; art as intuitive and spontaneous perception of reality

Maxim Gorkij je jednou z nejvýznamnějších osobností ruského kulturního života první třetiny 20. století. I když byly po něm už za Gorkého života pojmenovány města, letadla či instituce, je všeobecně známo, že rozsáhlé části jeho biografie se nemohou opřít o žádné metodologicky jednoznačně důvěryhodné zdroje.

Gorkého trilogie Детство (1913), В людях (1916), Мои университеть (1923) je podkladem pro všechny vědecké biografie Maxima Gorkého, především pak její první část Dětství. Je jediným zdrojem našeho vědění o dětství Maxima Gorkého konce 19. a začátku 20. století. Dětské roky Maxima Gorkého se staly čítankovými příklady člověka, který se ze společenského dna vypracoval na jednoho z největších literátů 20. století. Mnohokrát citovaná fakta, životní situace mladého Pěškova i surová dramata jeho dětství se stala součástí národního povědomí a klasickým portrétem městské ruské provincie a sociální spodiny konce 19. století.

Existuje Летописъ жизни и творчества А. М. Горъкого (I-IV. Moskva, 1958-1960). $\mathrm{V}$ této vědecké práci jsou chronologicky, den za dnem a hodinu za hodinou popsána všechna známá fakta o životě a díle tohoto ruského klasika. Ovšem i tato čtyřdílná svědectví se částečně opírají o Gorkého umělecké dílo a mají svá bílá místa, a tím i limitovanou spolehlivost.

Ve dvacátých letech 20. století, tedy v době Gorkého velké popularity, která nebyla ve srovnání s devadesátými lety předchozího století až tak velká, se rozhodl Michail Leonidovič Slonimskij jako člen literární skupiny Serapionovi bratři, že se stane biografem Maxima Gorkého a začal shromaždovat dostupná svědectví, materiály a dokumenty o Gorkého životě. Ovšem největší práci v tomto směru udělal Ilja Alexandrovič Gruzděv, který po něm tuto roli záhy převzal. Gruzděv byl literární historik, kritik, prozaik a rovněž také člen skupiny Serapionovi bratři. A byl to právě Gruzděv, který se zasloužil o to, že některé dokumenty o Gorkého raném dětství byly zachovány a utříděny a byly publikovány v knize Горький и его время. ${ }^{2}$ Ovšem v mnohém se musel Gruzděv spoléhat pouze na Gorkého vzpomínky a velmi kusé autobiografické poznámky, který byly Gorkým napsány v devadesátých letech a na přelomu 19. a 20. století, kdy byla sláva M. Gorkého na vrcholu. Velmi důležitým zdrojem (ovšem opět ne nezávislým) je korespondence Gruzděva s Maximem Gorkým. V letech 1920-1930 se Gruzděv mnohokrát, opakovaně, vytrvale a důrazně pokoušel kontaktovat Maxima Gorkého v souvislosti s fakty jeho raného dětství. Gorkij těmto snahám sice zjevně nakloněný nebyl, ale přesto pravidelně

1 Gor'kij, M.: Sobranije sočinenij: V 30t. Moskva: Gos. izd-vo chudožestvennoj literatury, 1951. T. 13. Detstvo. V ljudjach. Moi universitety.

2 Gruzdev, I. A.: Gor'kij i jego vremja. Moskva: Sovetskij pisatel', 1948; Gruzdev, I. A.: Gor'kij i jego vremja. Moskva: Gosudarstvennoje izdatel'stvo chudožestvennoj literatury. 
odpovídal. Důležitým zdrojem faktů o Gorkého životě jsou i povídky ze dvacátých porevolučních let, ze kterých je možné jisté fakty odvodit a jisté životní situace vysledovat.

Ovšem stejně jako Gorkého trilogie, tak i povídky Po Rusi (Пo Pycu 1912-1913, 1915-1917)3 , tak i Povídky z let 1922-24 nebo Poznámky z deniku. Vzpominky. (Рассказы 1922-1924 годов (1922-1924) Заметки из дневника. Воспоминания 1924) 4 jsou umе̌leckými texty, ve kterých prvotní autor mlčí, protože vypravěčské slovo nemůže být jeho vlastním slovem, stanoviskem, myšlenkou. Metodologicky tento jev popsal Michail Bachtin v dnes už klasické studii Estetika slovesné tvorby: „Создаюший образ (то есть первичный автор) никогда не может войти ни в какой созданный им образ. Слово первичного автора не может быть собственным словом: оно нуждается в освящении чем-то высшим и безличным (научными аргументами, әкспериментом, обвективными данньмми, вдохновением, наитием, властью и т. п.). Первичный автор, если он выступает с прямым словом, не может быть просто писателем: от лича писателя ничего нельзя сказать (писатель превращается в публиииста, моралиста, ученого и т. п.). Поэтому первичный автор облекается в молчание."

Ovšem Gorkého mlčení má ještě jeden aspekt. V drtivé většině Gorkého prózy mlčí také vypravěč a mlčí i postavy. Máme na mysli mlčení, při němž se vypravěč a postavy vyjadřují k okolnímu světu tak, že ho zrcadlí, reflektují (reflektor ${ }^{6}$ ), ale nekomentují to, co vidí. Před čtenářem se tak rozevírá dlouhý řetěz faktů, událostí, situací a postav, jejichž prostřednictvím je nahlížena románová realita, ale není zaujímán explicitně komentující a hodnotící postoj. Ve většině případů jsou portréty a situace pouze předváděny jako by na scéně a jsou ponechány ve stádiu situační a portrétní registrace bez přímého hodnotícího stanoviska. Portréty postav a situační obrazy jsou především viděny jako otazník. Tedy z tohoto hlediska mlčí Gorkij, který ani nemůže prostřednictvím uměleckého textu přímočaře promluvit, ale ve většině př́ípadů mlčí i vypravěč a mlčí i postavy. Máme zde na mysli Gorkého uměleckou literaturu a postavy typu Fomy Gordějeva (Foma Gordějev, Фома Гордеев, 1899), Ilji Luněva (Tři, Tpoe, 1900), Petra Artamonova (Podnik Artamonových, Дело Артамоновых, 1925) či Klima Samgina (Život Klima Samgina, Жизнь Клима Самгина, 1-1927, 2-1928, 3-1930, 4-1937). Klim Samgin registruje a mlčí a jestliže jako intelektuál promluví a vyjádří své stanovisko k okolnímu světu, vyvolá to následnou negativní a posměšnou reakci jeho okolí. Mlčení Klima Samgina vyvolávalo dojem moudrosti, která ví, ale mlčí. Z přímočarých Klimových slov začíná být najednou zřejmé, že nejenom že neví, ale navíc je jeho interpretace okolního světa neočekávaně naivní a neočekávaně prostoduchá. Pokusíme se ukázat na několika příkladech z Gorkého trilogie více než zdrženlivý hodnotící postoj jak postav, tak vypravěče. Samozřejmě jsme si vědomi schopnosti Gorkého textů vyjadřovat implicitní hodnotící stanoviska tak, jak je pro uměleckou literaturu běžné. Nicméně Gorkého věhlas v Rusku v druhé polovině

3 Gor'kij, M.: Sobranije sočinenij: V 30t. Moskva: Gos. izd-vo chudožestvennoj literatury, 1951. Povesti. T. 10.

4 Gor'kij, M.: Polnoje sobranie sočinenij: chudožestvennyje proizvedenija: V 25t. Moskva: Nauka, 1973. T. 17: Zametki iz dnevnika. Vospominanija: Rasskazy 1922-1294 godov.

5 Bachtin, M. M.: Èstetika slovesnogo tvorčestva. Moskva: Iskusstvo, 1979, c. 353; Èpštejn, M. N.: Slovo i molčanije: Metafizika russkoj literatury. Moskva: Vysšaja škola, 2006.

6 Stanzel, Franz K.: Teorie vyprávěni. Překlad Jiří Stromšík. Praha: Odeon, 1988, s. 321. 
devadesátých let 19. století byl spojen s postoji společenského odporu a s postoji odmítajícími tradiční hodnoty a tradiční vidění světa (v mnoha případech spíše tradiční pseudohodnoty) a v jeho dílech by se dala očekávat explicitní a přímočará reakce na okolní svět. Ovšem jeho dílo promlouvá jinak.

Zmínili jsme, že první část trilogie Dětství, která je podkladem pro všechny vědecké biografie o životě Maxima Gorkého.

Gorkého trilogie by mohla být uvedena následující citací: „Началасъ и потекла со страшной быстротой густая, пестрая, невыразимо странная жизнъ. Она вспоминается мне, как суровая сказка, хорошо рассказанная добрым, но мучительно правдивым гением. Теперь, оживляя прошлое, я сам порою с трудом верю, что всё было именно так, как было, и многое хочется оспорить, отвергнуть - слишком обильна жестокостью темная жизнь «неумного племени». Но правда выше жалости, и ведъ не про себя я рассказываю, а про тот тесный, душный круг жутких впечатлений, в котором жил, - да и по сей день живет, простой русский человек."7

Uvedená Gorkého slova vyjadřují rozpor, na němž je, zdá se, vystavěna poetika větší části trilogie a nejenom trilogie, ale celého jeho díla. Stojí zde proti sobě z jedné strany svět uzavřený do minulosti, reprezentovaný mnohotvárným životním prostorem a nazírajícím vědomím člověka, ze strany druhé. Je to pozorovatel, který vše autenticky prožil a ted' mu s odstupem času tyto staré vjemy vyvstávají před očima a živelně se stávají současností. Vypravěč nahlí̌̌i dětství s odstupem času, a tedy z jiné perspektivy, než je bezprostřední aktuální prožitek. Časový odstup by možná chtěl dát vzpomínkám jistý řád a interpretaci, ale vše podléhá živelně se deroucímu proudu starých obrazů, zážitků a vjemů. I když jde ve vyprávění o oživování faktů, přece jen reminiscence faktu není ve vyprávění tím hlavním. Vše je uvozeno prostou, ale jen velmi těžko řešitelnou otázkou: proč toto všechno? k čemu to je? jaký to má všechno smysl? „... возникал у меня естественный, но неразрешимзй вопрос: - Зачем все это?“.

Tedy Gorkému nejde o prostý řetězec faktů. Je nahlížen proud času, událostí, scén, obrazů a rozmanitých výjevů, které jsou zajímavé jak svými vnějšími konturami, tak i (a možná především) otázkou o jejich komplexním smyslu a směřování. Vypravěč v první osobě nechává promlouvat především trýznivě pravdivého génia - proud reality, jejího dění, pohybu a proměny.

Gorkému Dětstvi dominuje trvání otázky o smyslu proudícího dění. Z toho plyne i velmi častá frekvence tázacího zájmena зачeм? Trvání této otázky je příznačné pro všechna Gorkého vrcholná díla a frekvence těchto otázek s postupem Gorkého tvưrčího vývoje narůstá a sílí.

Gorkij předkládá přirozené sdělení, proč nepodává odpovědi na kladené otázky, nebo, lépe řečeno, proč jeho vypravěč nemůže podat vysvětlení a hodnocení: „Я молча удивляюсь: разве можно спрашиватъ, о чем человек думает? И нельзя ответить на этот вопрос, - всегда думается сразу о многом: обо всем, ито есть перед глазами, о том, ито видели они вчера и год тому назад; всё это спутано, неуловимо, всё движется, изменяется.“

7 Všechny citace textů M. Gorkého: Gor'kij, M.: Sobranije sočinenij: V 30t. Moskva: Gos. izd-vo chudožestvennoj literatury, 1951. T. 13. Detstvo. V ljudjach. Moi universitety. 
Gorkého proud reality, a především jejîho dění, nedává odpovědi a Gorkij potvrzuje, že zde není a ani nemůže být autoritou, která by mohla dát řešení, vysvětlení, hierarchizovat jevy a poskytnout v nich orientaci. Protože jde stále o nepřetržitý a stále se měnící proud obrazů, událostí, dějů a příběhů. Trvající otázka se stále váže na měnící se a pro člověka nezvladatelný slitek času a prostoru. Gorkij předkládá realitu ne v jejím autorsky zvládnutém obrazu, ale v jejím živelném a právě se rodícím dění, toku a proudění, které nejsou usměrňovány apriorním uměleckým záměrem. Uvádí, že pamět se v tomto př́ípadě vymyká z kontroly vůle a rozumu. „А в то же время памлтъ, помимо воли моей, восстановляет картинъ прожитого." Vypravěč trilogie nemá proud reality pod kontrolou, ale dává mu volný průběh, nechává se unášet jeho tokem a marně se pokouší nacházet smysl probíhajícího dění. Vypravěčské komentáře, pokud je vůbec možné komentáři nazvat, kladou opět otázky, ne odpovědi. Autorská intuice předkládá proud reality, dění prostoru a času v jejich volném průběhu, vytváří iluzi nespoutaného živlu a vyslovuje otázky o smyslu všeho probíhajícího. Otázky nejsou vypravěčem uzavírány, ale stále znovu a znovu jsou aktivovány a stále znovu a znovu jsou ponechány otevřenými v jejich tázacím trvání.

Nespoutané, přímočaré síly toku skutečnosti se tak zcela minimálně podřizují apriornímu rámci autorského záměru. Jde o oživování minulosti, v níž by se chtělo na mnohé zapomenout, avšak neúprosného génia „pravdy“ nelze oklamat. I když se surovost materiálu vypravěči evidentně příčí, poddává se mu a nechává se unášet neusměrněným tokem minulosti. Ovšem záměr tady je: položit prostřednictvím textu otázku: Kdo jsem já, kdo vlastně byli lidé kolem mě a co se to se mnou vlastně všechno stalo? Jako bychom zde měli před sebou souvislou řadu uzavřených, na sobě značně nezávislých obrazů, do nichž se noří Aljošovo vědomí s kardinální otázkou o podstatě bytí a místu lidské existence $\mathrm{v}$ něm.

Tedy jednotlivé obrazy vnímáme nejen z hlediska do sebe uzavřené a zarámované minulosti, ale především v kontextu nejširších existenciálních souřadnic. Gorkého nezajímá ani tak minulost, ale zajímá ho současnost. Zajímá ho otázka, kterou je možné prostřednictvím minulosti položit. Minulost už není minulostí, ale je to jistým způsobem minulost interpretovaná současností - tedy dobou, kdy byla Gorkým napsána. Pro čtenáře nejsou pak nejdůležitější hrdinovy kauzální reakce na jednotliviny, ale celková atmosféra Aljošova životního pocitu, snaha o intuitivní a emotivní uchopení světa v jeho celku. V tomto způsobu vidění reality Gorkij pokračuje i v dalším vývoji děje: sebe samého pak srovnává s úlem, do kterého včely snáší med. Tedy jinými slovy: med a úl jsou metaforami lidského vědomí, které reflektuje a registruje životní situace, portréty, obrazy a děje, v jejichž komplexním smyslu se člověk nemůže zorientovat. „В детстве я представляю сам себя улвем, куда разные простые, серые люди сносили, как пчель, мед своих знаний и дум о жизни, щедро обогашая душу мою, кто чем мог. Часто мед этот бывал грязен и горек, но всякое знание - все-таки мед.“

Maxim Gorkij zachovává v podstatě stále stejný model vjemu skutečnosti: a to v průběhu jak celoživotního tvůrčího období, tak na posledních stránkách jeho románu Život Klima Samgina. Před očima čtenáře vyvstává dlouhá řada událostí, scén, obrazů, portrétů postav, barevných a výrazných detailů, kterým ovšem chybí souvztažnost. Maxim Gorkij 
není prozaik syžetu, ale je typem dlouhé linie chronologických výjevů, které mají zdůraznit jeden zásadní lidský vjem: a to otazník o nepostižitelném, stále znova je formujícím a do nekonečna ubíhajícím vztahu člověka a proměny okolního světa. Tato Gorkého otázka o nekonečné proměně a dění interakce subjektu a objektu je podstatou jeho umělecké tvorby obecně. Jádrem jeho tvorby je neustále se proměňující otazník o vztahu člověka $\mathrm{k}$ ubíhající a proměnlivé realitě. $\mathrm{V}$ jeho případě pak jde o otazník o proměně a podstatě ruského světa a jeho zvláštnostech, otazník o možnosti smysluplného a lidsky přiměřeného začlenění jedince do stavu okolního světa.

Pokud tedy chceme sestavit autorský portrét M. Gorkého, musíme mít na vědomí, že tento portrét je třeba vytvořit na základě celého jeho díla, životních faktů a znalosti ověřených Gorkého životních situací, postřehů současníků. Nemůžeme samozřejmě vyloučit, že se ještě mohou objevit nové archivní dokumenty, jež mohou být cenným vhledem do období jeho života v Sorentu a které by mohly mnohé napovědět o Gorkého názorech $\mathrm{v}$ těchto letech. Ale lze se domnívat, že dokument, který by definitivně osvětlil tajemství života člověka typu Maxima Gorkého neexistuje a ani nikdy neexistoval. Gorkij ve svém díle vyslovil vše, co chtěl a zároveň nás postavil před otázku, co že to vlastně řekl. Na tuto otázku jsme se snažili v této stati odpovědět. Ovšem před tuto otázku Gorkij postavil i sebe samého.

U Gorkého je důležitá reflexe skutečnosti v okamžiku neustálého posunu a proměny. Tato proměna je zachycena v řetězci obrazů, portrétů, postav, situací, scénických výjevů, psychologické mimiky aktérů a jejich dějů. Je třeba zdůraznit, že nikdy není nastolována vize skutečnosti v neutrální podobě. Vždy je daná scéna posunuta ke krajním významovým pólům. Za všemi uvedenými významovými výsečemi stojí základní otázka o smyslu celku a podstatě souhry jednotlivých významových vektorů. Za zásadní v Gorkého díle je třeba považovat pamět a časové prolínání událostí v aktuálním zrodu, časovém průběhu a jejich úsilí o začlenění do celkového běhu světa. Toto začleňování je nazíráno z hlediska mnohaletého odstupu. A tato nabídka jevů k interpretaci z časového odstupu jim dodává na závažnosti a odkazuje na jejich nadčasový význam. V případě Gorkého poetiky lze hovořit popisu a bezprostředním vidění dějové scény. $\mathrm{Z}$ tohoto hlediska lze konstatovat, že pouhý osobitý popis se v Gorkého uměleckém světě stává interpretací. V této poetice nelze očekávat přímočaré hodnotící soudy a explicitní komentáře, naopak, Gorkij staví právě na jejich absenci. Realita jeho děl mluví sama za sebe. Jde o proud událostí, rozhovorů a situačních portrétů, jež jsou charakterizovány několika výraznými rysy. Takto viděnými situačními scénami prochází mlčenlivý pozorovatel, který je schopen prostřednictvím několika málo výrazných detailů vyjádřit podstatu jevu v jeho bezprostřední impresi a psychologickém portrétu. Takto dokonale provedené, jednoduché, výrazné a výstižné obrazy jsou navlékány na dlouhou nit lineárního nesyžetového př́iběhu skutečnosti. Každý obrázek vypovídá svůj příběh a zařazuje se do proměnlivého kaleidoskopu celku se stále se vracející otázkou: proč?

Pokud máme v této rozsahem vymezené studii odpovědět na otázku, jak se umělecká kvalita trilogie podílí na vykreslení autorské tváře Maxima Gorkého, pak vedle věcných životních faktů jde především o autora, který vystavěl svou poetiku na umění samovypovídající scény, na jejíž smysl se stále znova a znova ptá. Jde o to, že bylo řečeno vše a Gor- 
kij se stále ptá, co že to vlastně ve skutečnosti bylo řečeno. A to je zřejmě rys, který lze do určité míry ztotožnit s živým Maximem Gorkým a jehož prostřednictvím lze ozřejmit na první pohled protichůdně působící Gorkého názory v různých obdobích jeho života. Gorkého umělecký text dává srozumitelné poselství: pamět je zatížena a přetížena nekonečným množstvím přesně viděných událostí, s jejichž komplexním smyslem si autor neví rady. Maxim Gorkij je autor, který napsal rozsáhlé dílo. Napsal vše, co pokládal za podstatné, aby se stále znova a znova ptal po podstatě toho, co vyslovil. Tato situace vytváří možnou paralelu ke kontroverzním situacím ve skutečném životě Maxima Gorkého. Gorkého umělecké texty vyjadřují jeho skutečné a vždy nepřímé chápání světa.

prof. PhDr. Zdeněk Pechal, CSc.

Katedra slavistiky

Filozofická fakulta, Univerzita Palackého Olomouc

Křížkovského 10, 77180 Olomouc, Česká republika

zdenek.pechal@upol.cz 
